\title{
Analysis of Gender and Environmental Security Gaps in Nigeria: Experience from the Niger Delta Region
}

\author{
${ }^{1}$ Luke Amadi, ${ }^{2}$ Mina Ogbanga \\ ${ }^{1}$ Department of Political Science and Administrative Studies, University of Port Harcourt, Nigeria \\ ${ }^{2}$ Department of Sociology University of Port Harcourt, Nigeria
}

\begin{abstract}
Human security studies have deconstructed the state centric notion of security which centers on territorial boundaries and provides novel insights on micro level analysis of security studies within human dimensions. In this unfolding dynamic, the human dimension has not engaged substantially with gender security both as a distinct field of study or approach to non-traditional security study. This article is a theoretical exploration which attempts to conceptualize gender security to identify a myriad environmental insecurity triggers in the Niger Delta region of Nigeria associated with multinational oil companies and oil resource extraction such as oil spill, pollution, acid rains, gas flaring etc. The study deployed a relational content analysis (RCA) methodology to explore relevant secondary data on issues surrounding gender and environmental security in the Niger Delta. The aim is to create a relationship between environment and gender security and consider why human security arguments should be broadened to distinctively explore gender security as a specific pillar of security study. Findings suggest that international policy discourse in this regard has not made a significant impact in gender security studies. The article concludes that human security scholarship must transcend its narrow conceptual underpinnings if it is to make a lasting impact upon security studies, such overarching efforts should include prioritizing gender security as integral to security equality and amelioration of women's vulnerability.
\end{abstract}

Keywords: Gender Security, Vulnerability, Environmental Security, Development.

\section{INTRODUCTION}

A few decades to the end of the Cold War, environmental security consciousness held a novel sway in the United States following the publication in 1962 of the book; The Silent Spring (Carson, 1962).This was closely followed by Lynn White $\operatorname{Jr}(1967)$, The Historical Roots of Our Ecological Crisis, Garret Hardin (1968),Tragedy of the Commons and Paul Ehrlich(1968),Population Bomb.

Later in 1968, a group of scientists known as the Club of Rome provided the report; Limits to Growth (Meadows, et al; 1972) which gave greater impetus to environmental consciousness that saw the emergence of the Stockholm conference of 1972.

In the early 1980s, Richard Ullman (1983) and Jessica Mathews (1989) re-opened the debate on redefining security. Mathews (1989) identified the existing gaps in security debates within the environmental contexts and argued on unit level analysis with emphasis on human security. The late 1980s was the first comprehensive global policy discourse on environmental sustainability following the Brundtland Commission report: Our Common Future (WCED, 1987).

At the end of the Cold War, global security challenges within states stimulated greater interest in debates on "redefining security"(UNDP,1994; Klare,1996; Dewdney \& Matthew, 1999; Lowi \& Shaw, 2000; Paris,2001;Barnett, 2001). In particular, the Rio report of 1992 reasserted novel global relevance on environmental security discourse while the Copenhagen School of Security Studies (Buzan, et al.,1997) is considered the leading study that argued about broadening and deepening the security concept from military and political to societal, economic and environmental threats including identity (societal security).

There are debates which posit that environmental security studies had evolved in some phases (Rønnfeldt, 1997; Dalby, 2002). Simeon Dalby (2002:3) contends that first phase aimed at a wider comprehension of security beyond the Cold War discourses. The second, encompassed scholars that 
sought to identify connections between environment and insecurity, the third phase encompasses empirical substantiation or repudiation of the earlier propositions, the fourth phase included further synthesis and reconceptualizations. This perhaps is the ongoing phase. This study emphasizes the inclusion of gender security at this phase.

Dalby, et al.,(2009)argued that the fourth phase should be broadened and more encompassing against the narrow and Eurocentric perspectives of prevailing security debates emanating from the global North. Such narrow Eurocentric perspectives informed the increasing need to critically explore the environmental security dynamics of the coastal Niger Delta from human angle. Human security became such micro security concern at the post -Cold War era. It is understood within its four pillars: freedom from fear, from want, from hazard impacts and to live in dignity within a state of law (UNDP, 1994; Ogata, 2001; Ogata \& Sen, 2003; Bogardi \& Brauch, 2005; Brauch, 2005; Annan, 2005).

The Human Development Report, (1994), provides the most seminal articulation of human security. It argues that environmental factors are among its salient themes and reveals that "environmental security" refers to threats of air pollution, climate changes, ozone depletion, greenhouse gases, biological-diversity reduction, coastal marine pollution, and global fish catch reductions. It clearly suggests preventive rather than anticipatory modes of security threats amelioration. The report emphasized women vulnerability but did not clearly delineate gender security either as a distinct subject matter or security paradigm. It observed that; "among the worst personal threats are those to women. In no society are women secure or treated equally to men. Personal insecurity shadows them from cradle to grave" (UNDP, 1994: 6). The human security paradigm has provided an influential discourse in security studies (Brauch, 2005; Dalby, 2008). Ogata \& Sen, (2003) observe that the term "human security" provides important insight to understand core daily security issues such as the security of the people. They argue that human security provides a paradigm shift from the traditional perspectives which centers on the state as security provider.

The 21 st century's advances in human security have been conceived remarkable. At the individual level, human security nexus could be aptly extended to the exploration of gender security as the paper seeks to create such possible linkages. However, gender security threats persist despite the remarkable strides on human security debates, all over the world and in a number of dimensions such as cultural practices, rape, social deprivations, domestic violence, and gender discrimination etc (Oswald, 2008). The concerns on security of the common people such as women believed to be most vulnerable and subjected to security threats on a daily basis increasingly re-emerged.

Betty Reardon (1996) provided one the foremost analysis related to gender security issues. In her perspectives, gender- related violence is traced to masculine behavior and institutional marginalization of women. Brauch et al., (2008) sectorialized the security debate (health, water, energy, food, livelihood security), while Oswald (2008) deepened the gender security debate and argued that the scant study on gender security is an attribute of several decades of women's marginalization like most gender related issues. This supports the thesis of this paper which suggests that there seems to be scant studies specifically evaluating gender and environmental security nexus in the Niger Delta region of Nigeria like most coastal regions of Africa, Asia and Latin America.

Recent concern on gender security primarily emanated from women's clamor for greater participation in governance and decision making and in particular the increasing vulnerability of women in the general spheres of life. This became part of the programs and projects of international development agencies especially at post Beijing summit. Despite these, gender security transformation has been minimal (Oswald, 2008).Mohamed Ayoob, (1995) underscored the security predicament of the Third World which provides seminal insights into the dynamics of individual and institutional security threats of the periphery societies. He identified lack of "Stateness" and "systemic institutional failure" as partly accounting for insecurity.

The World Bank's 2011 World Development report shows that at least 1.5 billion people are still affected by current violence or its legacies. The report shows how 21 st century organized violence appears to be spurred by a range of domestic and international stresses, such as youth unemployment, income shocks, tensions among ethnic, religious or social groups, and trafficking networks (World Bank, 2011). Africa is more prone to environmental problems due to persistent wars, conflicts, and reliance on agriculture for livelihood (Engelman \& Anastasion, 2003; Amadi and Alapiki,2014). 
Particularly, the resource rich Niger Delta is prone to hazardous oil resource exploitation by Western Multi- national Oil Companies (MNOCs)which are primary triggers of environmental insecurity including hazards such as water and soil pollution, gas flaring, acid rains, etc which put women and the girl child on a high risk(UNDP,2006;UNEP,2011).

Ideas about gender security are implicit components of global peace, security and sustainable development. The central research question the paper seeks to explore is how environmental factors affect gender security. There is perhaps scant debate over what is meant by gender security. This article demonstrates that gender security constitutes the standard for determining the severity or otherwise of women's vulnerability. Such novel contributions underlie and define how the overall position of women is framed in environmental, social, cultural, economic and political contexts. It shows the increasing need for policy direction towards gender security issues. These have globally remained a missing research agenda. Mary Caprioli (2005) contends that gender is deployed as a yardstick to decide acquisition of power, which has increasingly resulted in inequality.

The article argues that gender security issues are of urgent policy concern in contemporary security debate. It raises questions about how different perspectives towards the environment have affected interpretations of women's vulnerability and possible transformations. The rest of the article is structured briefly as follows; theoretical framework, dimensions of gender insecurity in the Niger Delta, conceptual connections between gender and environmental security, the primacy of gender security, conclusion and policy directions.

Table1. Ranking of Major Environmental Problems in the Niger-Delta

\begin{tabular}{|c|c|c|}
\hline Problem Type & Problem Subset & Priority Ranking \\
\hline Natural Environment & $\begin{array}{l}\text { Coaster/River bank erosion } \\
\text { Flooding } \\
\text { Sedimentation/Silt } \\
\text { Substance } \\
\text { Exotic (water hyacinth) }\end{array}$ & $\begin{array}{l}\text { Moderate } \\
\text { High } \\
\text { Moderate } \\
\text { Low } \\
\text { Low }\end{array}$ \\
\hline Development Related & $\begin{array}{l}\text { Land degradation/Soil fertility Loss } \\
\text { Agricultural decline/ shortened fallow } \\
\text { Delta forest loss(Mangrove) } \\
\text { Biodiversity depletion } \\
\text { Fishery Decline } \\
\text { Oil spillage } \\
\text { Gas flaring } \\
\text { Sewage and waste water } \\
\text { Other Chemical }\end{array}$ & $\begin{array}{l}\text { High } \\
\text { High } \\
\text { High } \\
\text { High } \\
\text { High } \\
\text { High } \\
\text { Moderate } \\
\text { High } \\
\text { Moderate }\end{array}$ \\
\hline
\end{tabular}

Source: Okon \& Egbon, 1999

\section{Materials AND Methods}

Since the late 1970s "redefining security" has been a central concern in security studies (Ullman, 1983).This palpable contention has become germane at the neo liberal order as security threats persist. This paper contributes to a new theoretical research inquiry which aims at broader conceptualization of security. It builds on the human security debate which has since the 1990s proven to be the most influential framework to explore security at the micro level. Annan (2000) reasserts the significance of human-centred approach to security to check the persistent threats to humanity by weapons of mass destruction, such as nuclear weapons. He further states that human security, does not necessarily imply absence of violent conflicts rather it includes human rights, access to education and health care, good governance, and provision of requisite opportunities for individuals to maximize their potentials.

Human Security as explicated is understood within its four pillars: freedom from fear, from want, from hazard impacts and to live in dignity within a state of law (Dalby et al., 2009).

The human security conceptual framework is suitable to examine gender security as Sen \& Ogata (2003) argue that human security entails provision of safety systems that supports human survival. It encompasses political, social, environmental, economic, cultural and public environments that add value to livelihood and dignity for peoples' desire for improved quality of life. It involves the 
concepts of "peace and development" which perhaps suitably explains humanity's immediate as well as long-term aspirations. Human security is concerned with safeguarding and expanding people's fundamental freedom (Sen, 1999). Similarly, Annan,(2000:1) corroborates this freedom encompassing "freedom from want, freedom from fear, and the freedom of future generations to inherit a healthy natural environment - these are the interrelated building blocks of human - and therefore national security". Thus, in providing a theoretical connection between human security and gender security on one hand and environmental security linkages on the other, the paper builds on Oswald (2008).The aim is to inject novel theoretical trajectory and plasticity in gender studies to counter biases in literature on women's vulnerability and enrich theoretical debates on advancing gender transformation which is the task this research inquiry seeks to accomplish. Our level of analysis would be local, with emphasis on the Niger Delta. The choice to study the Niger Delta region is informed by persistent environmental insecurity arising from oil exploration by multinational oil companies in the region as the region is prone to environmental hazards (Okoko, 2002; Amadi, et al; 2016).This would be linked to a broader conceptual elucidation of the research question which seeks to analyze the gender security gaps in the region and possible policy direction to address same.

\section{Conceptual Connections Between EnVironment AND Gender SECURITY}

The concept "gender security" appears vague at a cursory glance as gender has historically not been adequately explored within security studies. Hence, women and femininity have not been taken into serious consideration. Gender is described as the socially learned behaviors and expectations that are associated with the two sexes (Andersen, 1994; Ingraham, 1994). Conceptual debates show that security is a contested term and does not have a universally accepted definition.

The Copenhagen School of Security Studies (Buzan, et al., 1997) provided a conceptual edge which challenged the traditional ways of approaching security. Buzan, et al., (1997) argue that security affects all "human collectivities" and is influenced by sectors such as; the political, economic, societal and environmental ones.

They define security as "the absence of violence, or use of force". Like all social phenomenon, gender security is not an intellectually isolated concept, it is expedient to be contextualized which explicitly opens up the content, notion and character of gender thinking and the status of gender security studies in development discourse. Althuser (1969) had underscored the theoretical and ideological relevance of any concept. The term gender security is often used without any elucidation of its conceptual edge. Realists continue to reassert the narrow conception of security in its "state-centric, militaristic" definition of the term which as they argue emanate from a masculine bias inherent in the theory (Hoggensen \&Rottem, 2004; Alison, 2007; Romaniuk, 2009).

Despite efforts to provide clearer understanding of its key features, various literatures, stress that the marginalization of gender security theory constricts a broader understanding of women's vulnerability (Alison, 2007).

The literature on environmental security suggests that environmental security has been examined from a number of perspectives (Suhrke, 1995; Allenby, 2001). Recent debates posit that, environmental scarcity increases financial demands on the state for infrastructure. Thomas Homer-Dixon and a group of Canadian scientists known as the Toronto school emphasize the construction of scarcity by complex social and environmental processes which often lead to political instability (Homer-Dixon, 1999; Dalby, 2002).

Günther Baechler (1998) links environmental concerns more directly to development and social change in the South while the environmental thinking linked to the International Peace Research Institute, Oslo (PRIO), provided a contrary debate against the Toronto school as they argue that rather environmental resource scarcity- that violence over resources in the South occurs in the struggle to control abundant resources (de Soysa, 2000; Dalby, 2002). This perhaps underscores the ongoing experience in the resource rich but poor Niger Delta like most oil rich coastal periphery societies. Nazli Choucri (1992) identified aspects of migration associated with environmental security such as environmental degradation and displacement of people. Similar accounts have suggested that future security threats to the affluent North will come about because environmental degradation will lead to starvation and the collapse of societies in the South, leading in turn to a massive migration of "Environmental refugees" (Dalby, 2002). A number of literature point that the post- Cold War resurgence of gender security debate and women emancipation discourses became increasingly 
germane following the neoliberal currents as liberal democracy gave novel impetus to gender equality discourse in ways that encouraged the more equitable approaches evident in global gender summits (Amadi \&Amadi, 2015). However feminists have argued that women are least in security agenda (Cohn, 2004), such that the notion of gender insecurity is implicit in key accounts of interaction of gender inequality.

Oswald (2008) broadened the gender security debate linking it with human and environmental security concerns-such as gender equity, and human rights. Oswald(2008) identified a protracted identity that has resulted in persistent vulnerabilities and minimal self- reliant responses. This in her views is an attribute of "thousands of years of gender discrimination" which gives rise to poor living conditions and adverse social situations.

Gender security (GS) has a systematic understanding based on its evolution (empirical, epistemic, stand-point and postmodern feminist thinking). Oswald (2009:9) identified four phases of gender security; first is identity and social representation, the second is postmodern feminism which according to Oswald is linked to Genevieve Vaughan who provided some modalities to rise above gender violence, the third is linked to ecofeminism on gender violence, nature and environmental degradation. She argued that that the fourth encompasses new social movements focusing on peace movements, antiwar efforts, environmentalist's efforts and similar efforts against exclusive globalization (Oswald, 2009).

Feminists argue that taking gender security seriously entails an inclusive dynamics in ecology encompassing issues such as ecofeminism (Warren, 1990).Implicitly feminism differentiates relationships and individuals as the basic actors in the field, with a focus on human security and social justice (Teriff, et al., 2005). Caroline Thomas (2000) argued that contemporary violent conflicts have developed new security patterns and characteristics. Thomas (2000) identified poverty, famine and ecology as examples of the new types of threats.

Within post-modern feminist thinking on gender security a number of threats are discernible. Studies demonstrate that current consumption patterns of the global North threaten the South because of (a) the North' s extensive consumption of resources, and (b) the ecological and social disruptions caused in many rural areas of the South by that resource extraction (Dalby,2002;Redclift, 1996). Shiva (2002) demonstrated similar vulnerability in India with industrial companies sited at periphery societies at the margins of development. While this pattern is not the sole cause of Southern insecurity, it plays an important role overlooked in the neo-Malthusian specifications of conflict caused by resource shortages. This informed the prognosis of the political ecologists which is a critique of the neo Malthusian theory positing that political power structure and inequality in resource exploitation are critical to environmental security threats rather than population explosion (Watts and eet,1996;Amadi, et al; 2015).

The Niger Delta region aptly falls within this category. It is located at the Atlantic coast of Southern Nigeria and is the world's second largest delta and has a coastline of about $450 \mathrm{~km}$ that terminates at Imo river entrance (Awosika et al., 1992). The Niger Delta is about 20, $000 \mathrm{sq} / \mathrm{km}$. It is the largest wetland in Africa and among the third largest in the world (Kadafa, 2012). About 2,370 sq/km of the Niger Delta area consists creeks, rivers, estuaries and swamps which cover about $8600 \mathrm{sq} / \mathrm{km}$, the mangrove swamp extends about $1900 \mathrm{sq} / \mathrm{km}$ as the largest mangrove swamp in Africa (Awosika, 1995). The region is classified as a tropical rainforest. It has diverse species of flora and fauna including aquatic and terrestrial species.

The Niger Delta has a population of about 30 million people as of 2005, accounting for more than 23\% of Nigeria's total population (Census, 2006). This has Severely impacted the region's biodiversity, fish and non- fish stocks, the ecosystem and general marine life. In particular, denying women one of their major means of livelihood- fishing. Equally, Human Rights Watch, (1999) reports that cumulative hydrocarbons in streams in most parts of the Niger Delta are 360 and 680 times the European Union's permissible levels. Similar security implications on land impacted by oil spill have been reported as Frynas, (2000) suggests that such lands are unsuitable for farming over two decades later. 
Despite the growing enthusiasm and literature in the global North on security studies (Homer- Dixon, 1991; Deudney \& Matthew, 1999; Lowi \& Shaw, 2000; Barnett, 2001; Dalby, 2002), there seem to be scant studies specifically evaluating gender and environmental security nexus in the Niger Delta region.

Only a few studies have critically examined broader dynamics of Third World security predicament such as gender security (Ayoob, 1995; Pepinam, et al., 2009). There are equally limited literatures and discourses on gender and environmental security in Africa (Ejigu, 2009; Moyo, 2009; Alaga, 2011). This narrow Westerncentric conceptualization of security has rendered the research agenda ineffectual or at the best superficial.

Against this background, the reviewed literature suggests that there is increasing need for a broader conceptual edge which should redirect security debates at a micro level with emphasis on gender security related themes such as green sexuality (Amadi, 2014b). It appears that gender security is central to a wide range of activities, domestic, organizational, socio-economic, political, cultural etc. The resurgence of these gender insecurity triggers such as intimate partner violence (IPV), rape, rural and urban domestic violence, conflicts, food, water, climate change, environmental degradation, terrorism, etc informed the need to distinctively explore gender security gaps in line with Brauch et al., (2008) who advanced sectorial analysis of the security debate. What follows are the dimensions of gender insecurity in the Niger Delta.

\section{DiMENSIONS OF GENDER INSECURITY IN THE NiGER DELTA}

Gender security discourse which suffers a research lag is now the foundation for an entire order of women transformation. Niger Delta women are mainly breadwinners, hardworking and resourceful; their subsistence derives largely from the environment. They are increasingly alienated from the wherewithal for sustainable livelihood namely; a secure environment (Amadi, 2013).

The nexus between gender and environment security in the Niger Delta is traced to the discovery of crude oil in commercial quantity in Oloibiri in present Bayelsa State in 1956 and the vulnerability of women in the context of environmental hazards arising from oil exploitation by the Multinational oil Companies (MNOCs). With increasing environmental degradation, oil has become a "black gold" with a number of deleterious effects. One key issue of concern has remained the security of women. In recent decades, feminist debates adopt broad perspectives to explicate resurgent gender insecurity (Tickner,1992;Stacey,1993;Chant,2008). There is need to explicate specific dimensions of gender insecurity in the Niger Delta. Oswald (2008:9) contends that these gender insecurity dimensions are attributes of decades institutionalized social inequality.

The following environmental insecurity triggers would be explored; Acid rain, gas flaring, sea level rise, coastal erosion, oil spill, deforestation, poverty /insecurity nexus, environmental disasters, gender violence.

\subsection{Acid Rain}

Acid rains has an increasing effect on women in the Niger Delta whose livelihood relies on the environment(Amadi,2013).A recent study with water sample from rain, open wells and rivers after a Hydro- chemical analysis showed moderately low pH values of $4.98>5.12>5.23$ for rain, river and well water resources in the Niger Delta region ( Efe \& Mogborukor,2012 ).This scenario increasingly affects women's vulnerability who are directly involved in fetching water ,tilling the soil for agriculture (Picard,1995;Amadi,2013;Emuedo \& Emuedo,2014). Gas Flaring: A number of study shows the environmental insecurity implication of gas flaring in the region (Social Action, 2009; UNEP, 2011; UNDP, 2006). The wasteful burning of gas continues to pollute the local atmosphere with dire consequences for human health and the wellbeing of communities in the Niger Delta area; it increases infant mortality data?, reduces human lifespan and contributes to general impoverishment in the area(Social Action,2009).

Although data on gas flaring has been scant and seemingly unreliable, a commonly quoted estimate is that oil corporations in Nigeria flare, on the average, 2.5billion standard cubic feet (scf)of associated as daily in 2004.This the source of about 70million metric tons of Co2 emissions per year(UNDP,2004). 
Analysis of Gender and Environmental Security Gaps in Nigeria: Experience from the Niger Delta Region

Table2. "Best estimates" of gas flaring trends in selected countries

\begin{tabular}{|l|l|l|l|l|}
\hline Country & Flared gas & Share of world total (\%) & \multicolumn{2}{|l|}{$\begin{array}{l}\text { Ratio gas flared to oil } \\
\text { Produced (M3/toe) }\end{array}$} \\
\cline { 3 - 5 } & & & 1990 & 2000 \\
\hline Algeria & 6.8 & 6 & 79 & 101 \\
\hline Angola & 4.3 & 4 & n/a & 118 \\
\hline China & 3.2 & 3 & 37 & 74 \\
\hline Egypt & 0.9 & 1 & 66 & 23 \\
\hline Indonesia & 4.5 & 4 & 70 & 66 \\
\hline Iran & 10.5 & 10 & 250 & 56 \\
\hline Nigeria & 17.2 & 5 & n/a & 166 \\
\hline Mexico & 5.6 & 3 & 18 & 33 \\
\hline North Sea & 2.7 & 11 & n/a & 9 \\
\hline Russia & 11.5 & 4 & n/a & 77 \\
\hline Venezuela & 4.5 & 3 & 30 & 27 \\
\hline United States & 2.8 & 100 & 10 & 22 \\
\hline Other countries & 107.5 & & - & - \\
\hline
\end{tabular}

Source: Cedigaz, USEIA, OPEC, IEA, World Bank, HIS Energy Group, 2000

\subsection{Sea Level Rise}

The Niger Delta experiences persistent sea level rise which has implications for gender security (Awosika, 1995). Coastal settlements, as Ogbu \& Utang, (2007) report which are subjected under stress of demographic pressure and unsustainable oil exploitation, are equally under the threat of sea level rise. Their findings suggest that global projections of sea level rise put the area under future inundation of up to $100 \mathrm{~km}$ in land (Ogbu and Utang, 2007). This has divergent implications both on human and environmental security such as loss of land, persistent livelihoods vulnerability, loss of valuable Biodiversity, economic activities and decline in sea foods including fish and non -fish.

\subsection{Environmental Pollution}

A number of empirical studies have documented the effects of Oil exploitation by the multinational oil companies on environmental pollution in the Niger Delta which results gender insecurity. (UNDP, 2006; UNEP, 2011; Hennchen, 2011; Amadi, et al., 2014). This emerges in a number of ways including water pollution, oil spill on the farm land etc. The impacted areas

results poor agricultural yield and further expose women to environmental risks with hazardous effects(Amadi,2013).The UNEP (2011) report shows that pollution of soil by petroleum hydrocarbons in Ogoniland (one of the environmentally polluted communities in the Niger Delta)is extensive in land areas, sediments and swampland. The UNEP shows that the surface water throughout the creeks contains hydrocarbons. The highest reading of dissolved hydrocarbon in the water column, of 7,420 $\mu \mathrm{g} / \mathrm{l}$, was detected at Ataba-Otokroma, bordering the Gokana and Andoni Local Government Areas(UNEP,2011).

\subsection{Deforestation}

Deforestation and gender security nexus in the Niger Delta is traced to the persistent falling of trees which are both sources of firewood and means of livelihood for rural women. Oil pollution has a number of environmental security effects which particularly affect women and the girl child as the most vulnerable. This includes impacted water for drinking and domestic use. UNEP (2011)reports that effects in many intertidal creeks has left mangroves denuded of leaves and stems, leaving roots coated in a bitumen-like substance sometimes $1 \mathrm{~cm}$ or more thick.The report contends that trees impacted die including root crops such as cassava and yam

\subsection{The Poverty /Insecurity Nexus}

This remains a major dimension of gender insecurity in the Niger Delta. The wide poverty gap between men and women has been a correlate of women's vulnerability and insecurity (Meagher, 1999; Sudakasa, 2005 ;) There are issues of sex workers in most urban cities in the region s women are systemically disempowered. The oil workers promote the trade as a result of poverty (Ihayere, et al; 2014). 
A recent empirical study conducted in the Niger Delta showed that despite living on land that yields billions of dollars in oil exports poverty remains pervasive. In most communities and towns such as Ogbe-Ijaw, Ogidigben, Odidi, Eqwa, Batan, Olisaro and Benette Island amongst others, there is no electricity or potable water ( Ihayere, et al;2014). The inhabitants of these areas resort to open river, as source of drinking water where a number of domestic activities such as local laundry etc take place.

In comparative terms the UNDP (2006) data shows that there is poverty and low Human Development Index (HDI) with other resource rich regions. With HDI of 0.453, the area rates far below countries or regions with similar oil and gas resources. For example, the HDI for Saudi Arabia in 2000 stood at 0.800, while in 2003 the United Arab Emirates, Kuwait, Libya, Venezuela and Indonesia achieved scores of $0.849,0.844,0.799,0.772$ and 0.697 , respectively (UNDP,2006). The gender security implication is that women who constitute a larger part of this population are bread winners in most households and mostly poor and vulnerable(Amadi,2013;Emuedo and Emuedo,2014).Being subservient to men, servile poverty and rise in women-headed households remain issues of gender insecurity. More specifically gender security is confronted with feminization of poverty.

\subsection{Common Characterizations of the 'Feminisation of Poverty'}

- Women experience a higher incidence of poverty than men.

- Women experience greater depth/severity of poverty than men (that is, more women likely to suffer 'extreme' poverty than men).

- Women are prone to suffer more persistent/longer-term poverty than men.

- Women's disproportionate burden of poverty is rising relative to men.

- Women face more barriers to lifting themselves out of poverty.

- The 'feminisation of poverty' is linked with the 'feminisation of household headship'.

- Women-headed households are the 'poorest of the poor'.

- Female household headship transmits poverty to children ('inter-generational transmission of disadvantage')

Source: Chant,(2008).

\subsection{Environmental Disasters}

Although gender security in global contexts seem not to have been given adequate attention, its negative effects are strong among the poor societies such as the Niger Delta where the post 2012 flood disaster, triggered insecurity challenges including outward migration, displacement, refugee camps and loss of lives (Amadi,2013). Recent data from empirical study conducted at the post 2012 flooding in the Niger Delta revealed 95\% damage on farm lands and animals while several homes were submerged and many people internally displaced the study reports that women were mostly impacted as breadwinner and most vulnerable (Amadi \& Ogonor, 2015).

United Nations High Commissioner for Refugees (UNHCR), recounts the growing number of internally displaced persons and out migration in Africa (UNCHR, 2002). A study quantified the scale of the flooding in the Niger Delta region and reports that the unusual large floods were predicted by the Nigerian Meteorological Agency (NIMET). Government at all levels failed to act timely to mitigate the disaster. Communities in a record $30 \%$ of the country ${ }^{\text {ee }} \mathrm{s}$ landmass were submerged by the floods affecting an estimated 7.7 million persons. Well over 300 people were killed while more than two million people were displaced from their homes, farmlands, and homes were inundated in 30 of the 36 states of Nigeria women were the most impacted (Social Action,2012;Amadi,2013).

\subsection{Gender Violence}

Gender violence takes various forms. Such forms of gender based insecurity as violence specifically target women and girls because of their sex. These are referred to as "violence against women", including rape, domestic violence, murder, and sexual abuse (UNIFEM, 2007). Socially, there are conflicts, youth restiveness and hostage taking, a number of socio- cultural practices circumscribe the status of women and often affect female reproductive health, the female genital mutilation remains an issue of gender insecurity. Within the socioeconomic context are socially assigned gender based tasks 
and obligations. It is the women's task to provide for the upkeep of the family in the Niger Delta (Efe \& Mogborukor, 2012). Women face a number of such 11 insecurity challenges including social deprivation, cultural practices, violence, etc (Amadi, 2013).Women both in riverine and upland engage in activities that are tied to the environment. Such as farming and fishing (Okon, 2002; Amadi, 2013). Women are thus, - farmers, domesticators, food procurers and food producers (Okon, 2002).

Marriages in most Niger Delta communities have placed women in a disadvantage position beyond environmental and cultural threats; there is less commitment to fidelity. This does not denigrate Niger Delta men, it is relatively African. Marriage insecurity threatens an average Niger Delta woman. This scenario is mostly reflected in extra marital affairs, threats of polygamy and possible divorce. There are cases of intimate partner violence (IPV), rapes and similar cases of violation of women's rights in the Niger Delta(Turner \& Brownhill, 2007).

In relation to the MDG targets, the SIGI report underscored divergent evidence of persistence of women's vulnerability such as their control over resources, non- involvement in decision making both in the family and in the wider political circle, their poor involvement in, and over all control of their own physical security, point to a number of issues that impede progress across all the MDG targets. Similar challenges confront post MDG development global frameworks such as Sustainable Development Goals (SDGs) (Amadi et al;2015).

For instance, SIGI measures how social institutions, defined as long-lasting codes of conduct, norms, traditions, and formal and informal laws, impact on gender equality(OECD,2012). Several of these variables have been found to be particularly relevant to the outcomes used to measure MDG progress as outlined in table three which shows that globally women's "physical security" is among the missing dimensions of the Millennium Development Goals (MDGs).

Table3. The Missing Dimensions of the Millennium Development Goals

\begin{tabular}{|l|l|l|l|}
\hline MDGs & Targets & Indicators & The missingdimensions? \\
\hline $\begin{array}{l}\text { MDG 1: Eradicate } \\
\text { extreme hunger } \\
\text { and poverty }\end{array}$ & $\begin{array}{l}\text { 1.C: Halve, } \\
\text { between } 1990 \text { and } \\
2015, \text { the } \\
\text { proportion of } \\
\text { people who suffer } \\
\text { from hunger }\end{array}$ & $\begin{array}{l}\text { 1.8: Prevalence of } \\
\text { underweight } \\
\text { children under five } \\
\text { years of age }\end{array}$ & $\begin{array}{l}\text { Women's control } \\
\text { over resources: } \\
\text { access to land and } \\
\text { credit }\end{array}$ \\
\hline $\begin{array}{l}\text { MDG 2: Achieve } \\
\text { universal primary }\end{array}$ & $\begin{array}{l}\text { 2.A: Ensure that, by } \\
\text { 2015, children } \\
\text { everywhere, boys } \\
\text { and girls alike, will } \\
\text { be able to complete } \\
\text { a full course of } \\
\text { primary schooling }\end{array}$ & $\begin{array}{l}\text { 2.2: Proportion of } \\
\text { pupils starting } \\
\text { grade 1 who reach } \\
\text { last grade of } \\
\text { primary }\end{array}$ & $\begin{array}{l}\text { Women's decision making } \\
\text { power: } \\
\text { percentage of } \\
\text { women married, } \\
\text { aged 15-19 years }\end{array}$ \\
\hline $\begin{array}{l}\text { MDG 5: Improve } \\
\text { maternal health }\end{array}$ & $\begin{array}{l}\text { 5.A: Reduce by } \\
\text { three quarters, } \\
\text { between 1990 and } \\
\text { 2015, the maternal } \\
\text { mortality ratio }\end{array}$ & $\begin{array}{l}\text { 5.1: Maternal } \\
\text { mortality ratio }\end{array}$ & $\begin{array}{l}\text { Women's physical } \\
\text { security: level of } \\
\text { violence against } \\
\text { women and female } \\
\text { genital mutilation }\end{array}$ \\
\hline
\end{tabular}

Source: $O E C D 2012$

Table4. Gender Security Paradigms from Post-World War II to Post-Cold War

\begin{tabular}{|l|l|l|}
\hline Period & \multicolumn{1}{|c|}{ Perspective } & Status and meaning of Security in gender context \\
\hline 1945 & End of Second World War & International Peace and Security \\
\hline 1950 & $\begin{array}{l}\text { Modernization/World } \\
\text { Systems Analysis }\end{array}$ & $\begin{array}{l}\text { Western-centric and Systemic/alliance/territorial security } \\
\text { against unit level analysis. }\end{array}$ \\
\hline 1960 & $\begin{array}{l}\text { Third World vulnerability and } \\
\text { dependency }\end{array}$ & Structural inequality in the international system \\
\hline $1970 \mathrm{~s}$ & Stockholm conference & Non emphasis on gender security \\
\hline $1970 \mathrm{~s}$ & First world Women Conference & Minimal emphasis on gender security \\
\hline 1980 & $\begin{array}{l}\text { Global ideological Warfare/ } \\
\text { inception of Sustainable }\end{array}$ & The cold war and global insecurity \\
\hline
\end{tabular}




\begin{tabular}{|l|l|l|}
\hline \hline & development as a global project & \\
\hline 1990 & End of cold War & Neo liberalism and human security \\
\hline 1990 s & $\begin{array}{l}\text { The Beijing platform for } \\
\text { Action(BPA) addressed peace and } \\
\text { security issues(1995) }\end{array}$ & $\begin{array}{l}\text { Redefining security from human dimension, "Gender } \\
\text { mainstreaming" became official UN policy with no } \\
\text { concerted interface within the gender security realm. }\end{array}$ \\
\hline 2000 & Millennium Development project & $\begin{array}{l}\text { Minimal emphasis on women's } \\
\text { security }\end{array}$ \\
\hline 2000 & $\begin{array}{l}\text { Regional Insecurity in the global } \\
\text { South }\end{array}$ & $\begin{array}{l}\text { Resurgent new wars, local conflicts and insecurity in the } \\
\text { global South specifically Africa and Asia at the post- cold } \\
\text { war }\end{array}$ \\
\hline $\begin{array}{l}\text { Thanimously adopted Resolution } \\
\text { 1325 }\end{array}$ & $\begin{array}{l}\text { Adoption of women peace and security resolution and } \\
\text { novel quest for global gender security. }\end{array}$ \\
\hline
\end{tabular}

Source: Authors

\section{The Primacy of Gender SeCUrity}

The primacy of gender security among several factors aims at restoring the status of women through mitigation or removal of security threats. As broad as it is, gender security has been given a far too narrow attention. Feminists have argued that women are least in security agenda (Grant 1993;Cohn,2004;), such that the notion of gender security, is implicit in key accounts of interaction of gender inequality. Again, the concept of gender security from the above premise applies to the security of women, though gender encompasses both sexes, we have chosen to consign it to women in line with dominant and conventional modes of exploring gender discourse which demonstrates the primacy of women in terms of their vulnerability and socio-cultural alienation.

Feminists have observed that men have long been ascribed certain characteristics such as "strength, power, autonomy, independence and rationality"(Caprioli,2005). For these reasons, men have often been considered stronger than women and this wholly translates to every critical facet of human endeavor bringing into question the notion of inequality and gender based discrimination where women are seen as weak, peaceful, cooperative and reliant on men for their protection (Hudson, 2009; Romaniuk, 2009).

Gender security research at post Beijing Summit and Beijing Plan of Action (BPA) has consistently stressed the importance of broader conceptual frameworks to mainstream gender security into all facets of development discourse. Much of these were espoused in the human security debates of the 1990s but have not been prioritized in policy framings at a closer explication of the three phases of GS studies (Oswald,2008). To theorize in terms of social realities is to have a way of making sense of concepts in relation to pervasive social patterns (Ingraham, 1994). The focus is on gender security theory:

Gender security is organized reflections on protecting the status of women. Gender security is a woman who did not bleed to death at child birth, a girl child not raped or sexually harassed, a girl child protected against HIV/AIDS, a woman shielded against environmental hazards and deleterious resource use, women whose voices are heard in making decisions affecting them, a girl child protected against sexual exploitation and prostitution, a woman whose livelihood is protected from anthropogenic environmental choices; a woman who is not a sex tool or stooge in her marriage.

The primacy of gender security is beyond protecting women against wars or local conflicts. In this context, it is taken to include attention to the special daily needs, social protection and existential realities of women from the household down to the streets, in workplaces and in churches. It is a move against gender-based violence, and an end to impunity for crimes of violence against women including unruly behavior and unfair treatment to women, it explores men's immodest and immoral acts -the plights of battered women, family vulnerability such as women being entirely responsible for household chores, entirely attending to the sick children, the elderly.

It involves organizing the family and coping with crises, protecting women's death at child birth, child rearing from cradle to adulthood, removal of the oppressive cultural practices such as widowhood, genital mutilation, displacement of women, men's infidelity and women's marriage insecurity, sexual exploitation of women, insecurity of conception, insecurity of livelihood and living, 
discrimination in employment and white collar jobs, women's rehabilitation psychological and social rehabilitation, effective reintegration-politically, socially, economically, religiously and culturally including Muslim practices which relegate women to the purdahs, as well as measures supporting local women's voices in key decisions affecting them.

Since gender theories are also organized policy frameworks, the primacy of gender security approach encompasses gender equality; but definite gender emancipation policies are largely informed by a number of factors, this debate as evidenced primarily focuses on gender security. According to this perspective, gender security is interrelated with other forms of security but has not been identified either as a distinct field or analytical tool of study. Other types of vulnerability, whether economic or ecological become integral components of our definition of gender security only if they become acute enough to acquire developmental dimension and threaten women security. In other words, sociopolitical and economic marginalization, cultural practices, sexual exploitation, child marriage, taboos etc are sub category of phenomena that could pose latent or manifest threats to gender security.

Gender security in contemporary time's calls for a rethinking and possible positive impacts on gender equality debate, contributing to the growing discourse on institutional frameworks such as the Millennium Development Goals (MDGs) which gender inequality is one of its pillars. It follows that gender security is now a proposition designed to explore women's vulnerability encompassing environmental, social and economic strands which are components of sustainable development. Beyond the schism which seems to have evolved between the limits of the gender security discourse and the more inclusive and broader conceptualizations of gender, another implicit challenge is that in the light of disparities between a number of women's opportunities and capabilities - particularly in cultural practices, politics, education and employment - gender gaps inevitably remains wider.

The status of gender security thus reflects a theory-lag between security studies and international development generally, and a recurring gender inequality and women's vulnerability. This is partly because of the Western centric notion of gender security studies as in particular, neoliberal policies demonstrate less commitment to gender transformation especially in the global South, applying Western standards of policy and systems which do not understand what is contingent or essential to women's security needs especially in Africa where patrimonial autocracy subsume gender transformation.

The definition of security used here purports to be development centric in character emphasizing equality and the fundamental development connotation of the term gender security and the major enterprise in which women have been engaged in the context of gender security transformation since the end of the Cold War and resurgent neo liberal order. This is consistent with well-known conceptualization of development as freedom (Sen,1999). Thus, gender security ought to be synonymous to the freedom Sen had argued. However, this emphasis on the primacy of gender within the development realm in the definition of security does not mean that the development realm can or should be totally insulated from other realms of human and social activity when it comes to dealing with gender security issues neither does the emphasis on gender security as argued here vitiates other forms of security. Mary Caprioli contends that although it retains its primacy in the definition of security, gender is the basis of structural inequality in all societies (Caprioli, 2005). It determines roles, power, relationships, responsibilities, expectations, and access to resources (UNDFA, 2003).

Thus, gender forms a key yardstick for sex roles and determination of socio-economic status (Althuser, 1969). Gender hierarchy reinforces itself through system of rules and penalties; enforced in all aspects of life (Hoogensen \& Rottem, 2004). However, the influence of the other aspects on matters that affect gender must be filtered through the security realm and must be directly linked to women's security emancipation. In other words, other aspects of life -such as domestic,cultural, environmental, economic to the social -seem to have effects on gender and thus threaten gender security as in our case example in the Niger Delta, these other variables must be taken into account as a part of a coherent whole that make up development and sustainable gender security transformation.

Again, gender security within the development realm finds plausible expression in the sustainability debate (Hoggensen \& Rothem, 2004). It seeks to answer the question of "security sustainability", "security expansionism" and "security revisionism". Thus, gender security should be given requisite attention in sustainable development discourse. Short of that, the development and security realm will remain superficial and uncritical. Phenomena such as economic deprivation, socio-cultural alienation and environmental degradation should be analyzed as events or occurrences and variables that may 
be linked to a broader elucidation of gender security either as oppositional (threats) or supportive strands (components) of gender security.

Despite our postulations, a major empirical limitation has been the question of quantification of environmental security threats (Alcamo,1999).This opens this study to a further research.

\section{Conclusion ANd Policy Directions}

To meet the theoretical goal of this study, the article demonstrated that gender security is guaranteed to the extent that women are not in danger of sacrificing their values or wishes to external threats or pressure. Meeting gender security needs must illustrate the ways in which the daily lives of women transcend some of the traditional barriers that place obstacles to their socio-economic transformation (Romaniuk, 2009). The article has attempted a conceptualization of gender security and explored the dimensions of environmental and gender security challenges in the Niger Delta region.

International collaboration to alleviate gender insecurity is pertinent. The idea of mobilizing global policy frameworks and all stakeholders for a collective action for gender security transformation is critical.

The current international development paradigm centres on stimulating gender equality as the fundamental mechanism for facilitating progress in sustainable development. The seminal explication of this development paradigm could be found in gender transformation blueprints such as the Beijing Plan for Action. Our study has added impetus to the urgency of gender security transformation which has been given minimal attention.

Thus, gender security is the centre piece of transformation of woman which this paper has demonstrated substantially. The paper has undertaken to explore gender security due to a number of global unfolding dynamics. First is the rise in environmental degradation and hazards in natural resource extraction by the oil multinational companies in the Niger Delta and increase in cultural practices that pose threats to women as well as the post- Cold War resurgence of local conflicts such as terrorism in the global South, persistent wars and sexual violence and need for novel security dynamics for women hence a concrete conceptualization of gender security framework is sought.

On its part, the article had demonstrated that environmental security threats are inter-linked, and require inclusive participatory approach. Such broader approach should adopt a gendered perspective if solutions are to be reached. This will bring women on track, recognizing their special relationship with the natural environment, and the increasing need for their security.

\section{REFERENCES}

Alaga E (2011).Gender and Security Policy in West Africa A working paper Friedrich-Ebert-Stiftung: Gender and Security Policy in West Africa. Pp.1-24

Alcamo, J. (1999). "Environment, Security, and the question of quantification," in A climate for change (pp 147-170) M. Kok \& W. Groot (Eds.). Utrecht, The Netherlands: Jan van Arkal Publishing.

Alison, M. (2007). "Wartime Sexual Violence: Women's Human Rights and Questions of Masculinity." Review of International Studies, No. 33 pp.75-90.

Althuser, R(1969). For Marx. London: New Left Books.

Amadi, L (2013). Climate Change, Peasantry and Rural Food Production Decline in the Niger Delta Region: A case of the 2012 flood disaster. Journal of Agricultural and Crop Research Vol. 1(6), pp. $\mathrm{xxx}-\mathrm{xxx}$.

Amadi.L (2014b). “ Sexuality: Same Sex Marriage and Sustainable Human Development: Beyond Western Sexual Rights Perspective"in proceedings of the 3rd International Conference of the Transatlantic Research Group in collaboration with the Gender and Sexuality Resource Center, Women and Gender Studies Program, and Office of International Education Marquette, University Milwaukee, WI 53233 United States,Apr. 23-24, 2014.

Amadi L,Amadi C(2015). Towards Institutionalizing Gender Equality in Africa: How Effective are the Global Gender Summits and Conventions?: A Critique. African Journal of Political Science and International Relations Vol. 9(1) pp.12-26. 
Amadi L,Igwe P, Wordu S.(2014). Sustainable Development, Greening and Eco-efficiency -A Political Ecology Journal of Sustainable Development Studies.Volume 7, Number 2, 161-196

Amadi L,Ogbanga M and Agena J(2015) Climate change and feminist environmentalism in the Niger Delta, Nigeria. African Journal of Political Science and International Relations (AJPSIR) Vol. 9(9), pp. 361-371

Amadi L, Ogonor M (2015). Climate Change, Environmental Security and Displacement in Nigeria: Experience From the Niger Delta,African Journal of Environmental Science and Technology No 1 (9) pp53-64

Amadi L,Wordu S and Ogbanga M(2015) Sustainable Development in Crisis? A Post Development Perspective. Journal of Sustainable Development in Africa (Volume 17, No.1, 2015)

Annan.K "Report of the Secretary-General on the Work of the Organization". General Assembly Official Records Fifty-fifth session Supplement No.1 (A/55/1). New York: United Nations, 2000, p.4.

Annan K (2005) "Towards Development, Security and Human Rights for All". Available www.ohchr.org/Documents/Publications/A.59.2005.Add.3.pdf [Accessed 10/7/2014]

Andersen, M (1994). Thinking about Women. New York: St. Martin's

Awosika, L,G. French, R, Nicholls, C. Ibe, (1992). "The impacts of sea level rise on the coastline of Nigeria" in Global Climate Change and the Rising Challenge of the Sea. O'Callahan, J. (ed.). Proceedings of the IPCC Workshop at Margarita Island, Venezuela, 9-13.

Awosika L (1995).“Impacts of global climate change and sea level rise on coastal resources and energy development in Nigeria" in Global Climate Change: Impact on Energy Development Umolu, J. C. (ed.) DAMTECH Nigeria Limited, 1995.

Ayoob,M (1995). The third world security predicament: State making, regional conflict and the international system. London: Lynne Rienner Publishers.

Baechler, G (1998). "Why environmental transformation causes violence: A synthesis." Environmental Change and Security Project Report 4, 24-44.

Barnett, J. (2001). The meaning of environmental security: Ecological politics and policy in the new security era. London: Zed Books

Bogardi, J, Brauch H (2005). "Global Environmental Change: A Challenge for Human SecurityDefining and Conceptualising the Environment Dimension of Human Security", in: Andreas Rechkemmer (ed.). UNEO-Towards an International Enviornmental Organization-Approaches to a Sustainable Reform of Global Environmental Governance, Nomos, Baden-Baden, Germany: 85-109

Brauch, H (2005). Environment and Human Security. Towards Freedom from Hazard Impacts, UNUEHS, Intersection 2, UNU-EHS, Bonn, Germany.

Brauch H,Oswald U,Grin J,MesjaszC,Kameri-Mbote P, et al., (eds)(2008).Facing Global Environmental Change:Environmental,Human,Energy,Food,Health and Water security Concepts.Berlin Heidelberg-New York: Springer-Verlag

Buzan B,Waever O,wilde J( 1999).Security a New Framework for Analysis. Lynne Rienner Publishers

Caprioli, M (2005). Primed for Violence: The Role of Gender Inequality in Predicting Internal Conflict. Int. Stud. Q. 49:161-178

Carson, R (1962).Silent Spring. Houghton Mifflin

Chant, S (2008). The 'Feminisation of Poverty' and the 'Feminisation' of Anti-Poverty Programmes: Room for Revision? Journal of Development Studies, 44:2, 165 - 197.

Choucri,N(ed). (1992)."Environment, Development and International Assistance: Crucial Linkages,"in Resolving Third World Conflicts Challenges for a New Era,(ed); Sheryl J.Brown and Kimber M Schraub. Washington DC United States Institute of Peace Press,pp 89-118 Responses. Cambridge, Mass: MIT Press. 
Cohn, C (2004).Mainstreaming Gender in UN Security Policy: A Path to Political. Transformation? Working Paper No. 204Available at https://www.amherst.edu/.../ mainstreaming+gender+ in+UN+ security+policalAccessed 5/10/2014

Dalby, S (2008). Security and Environmental Change. London: Polity.

Dalby, S (2002).Security and Ecology in the Age of Globalization ECSP Report - Issue 8,95 : 95108.

Dalby S, Brauch H, Oswald U (eds),(2009). Environmental Security Concepts Revisited During the first Three Phases (1983-2006) in Facing Global Environmental Change:Environmental, Human, Energy,Food,Health and Water security Concepts.Berlin Heidelberg-New York: Springer-Verlag pp1520.

Deudney D, Matthew, R. (Eds.). (1999). Contested grounds: Security and conflict in the new environmental politics. Albany: State University of New York Press.

de Soysa, I (2000). “The resource curse: Are civil wars driven by rapacity or paucity?” In Mats Berdal and David M. Malone (Eds.), Greed and grievance: Economic agendas in civil wars (pages 113135). Boulder: Lynne Rienner

Efe, S, Mogborukor, J. (2012). "Acid Rain in Niger Delta Region: Implication on Water Resources Quality and Crisis AFRREV STECH, An International Journal of Science and Technology Bahir Dar, Ethiopia Vol.1 (1) January-March,pp.17-46.

Engelman,R, Anastasion, D(2003)."The Security Demographic - Population and Civil Conflict after the Cold War".Available http://populationaction.org/reports/the-security-demographicpopulation-and-civil-conflict-after-the-cold war/\#sthash.PqHKG28s.dpuf (Accessed: June.10, 2013)

Ejigu M (2009). Environmental Scarcity, Insecurity and Conflict The cases of Rwanda, Uganda, Ethiopia and Burundi in Facing Global Environmental Change: Environmental, Human, Energy,Food,Health and Water security Concepts.Brauch H etal;(eds)Berlin Heidelberg-New York: Springer-Verlag

Ehrlich P (1968). Population Bomb New York:Simeon and Schuster

Emuedo C, Emuedo O (2014).Oil activities, unsustainable environment and the combative reactionism of women in the Niger Delta. African Journal of Political Science and International Relations Vol.8 (1) pp.1-9

Frynas G (2000). Oil in Nigeria: Conflicts and Litigations Between Oil Companies and VillageCommunities, Hamburg: LIT Verlag Munster

Grant,J (1993). Fundamental Feminism. New York, NY: Routledge.

Hardin G. (1968). The Tragedy of the Commons. Science Vol. 162 no. 3859 pp. 1243-1248

Hemmings, C (2005) .Telling feminist stories Feminist Theory SAGE Publications,London, vol. 6(2): 115-139. 14647001

Hennchen, E. (2011). "The role of oil mayors in supporting sustainable peace and development in Nigeria: the case of Royal Dutch Shell", in M. Prandi \& J. M. Lozano (Eds.), CSR in conflict and post-conflict environments: from risk management to value creation. Barcelona: School for a Culture of Peace (UAB); Institute for Social Innovation (ESADE). p. 133-145

Hoogensen G, Rottem,S (2004)."Gender Identity and the Subject of Security." Security Dialogue, Vol. 35, No. 155-171.

Homer- Dixon,T (1991) “'On the Threshold: Environmental Changes as Causes of Acute Conflict" International Security. Trudeau Centre for Peace and Conflict Studies, University of Toronto International Security, Vol. 16, No. 2.

Homer-Dixon, T, Blitt, J. (Eds.). (1998). Ecoviolence: Links among environment, population and security. Lanham, Maryland: Rowman and Littlefield.

Homer-Dixon, T (1999). Environment, scarcity and violence. Princeton: Princeton University Press.

Hudson, H(2005).“Doing” Security As Though Humans Matter: A Feminist Perspective on Gender and the Politics of Human Security." Security Dialogue, Vol. 36, No. 2 pp. 155-174.

Human Rights Watch (1999). Corporate Responsibility and Human Rights Violations in Nigeria's Oil Producing Communities.Available at http://www.hrw.org.[Acessed on 10/1/2014]. 
Ihayere C, Fovwe D, Ataine T(2014). The effects of the Niger Delta oil crisis on women folks. Journal of African Studies and Development Vol. 6(1), pp. 14-21

Ingraham,C (1994).The Heterosexual Imaginary: Feminist Sociology and Theories of Gender" Sociological Theory, Vol. 12, No. 2 , pp. 203-219.

Kadafa,A (2012)."Oil Exploration and Spillage in the Niger Delta of Nigeria”. Civil and Environmental Research.Vol 2, No.3 pp.38-51

Klare M (1996). Redefining Security: The new global schisms in Globalization and the Challenges of a new century: A reader, O'Meara P, Mehlinger HD, Krain M (Eds.). pp. 131-139.

Lowi, M and Shaw, B (Eds.). (2000). Environment and security: Discourses and practices. London: Macmillan.

Mathews, J. (1989). Redefining Security, Foreign Affairs, 68:2 p.162.

Meagher, K (1999). If the Drumming Changes, the Dance also Changes: De-agrarianisation and Rural Non-Farm Employment in the Nigerian Savannah ASC Working Paper: De-agrarianisation and Rural Employment Network: Afrika Studies Centrum, Leiden and Centre for research and Documentation (CRD), Kano

Meadows D. et al.(1972), The Limits to Growth: A report for the Club of Rome's project on the predicament of mankind, Part 1 Club of Rome, Potomac Associates.

Moyo S (2009). Environmentl Security in Sub Saharan Africa in Facing Global Environmental Change:Environmental,Human,Energy,Food,Health and Water security Concepts.Brauch H, etal;(eds).Berlin Heidelberg-New York: Springer-Verlag.

Oakley, a (1972). Sex, Gender, and Society. London: Harper

OECD "Poverty reduction and social development.The OECD Social Institutions and Gender Index, 2012.Available http:// www.oecd. org/social/ poverty/ theoecdsocialinstitutionsand genderindex. htm [Accessed June 10,2014].

Obi, C (2001).The changing forms of identity politics in Nigeria under economic adjustment: The case of the oil minorities movement of the Niger Delta (Research Report No. 119). Nordiska Afrikainstitutet, Uppsala, Sweden.

Ogba,C, Utang,P (2007).“Nigeria Vulnerability and Adaptations of Nigeria's Niger Delta Coast Settlements to Sea Level Rise". Available https://www.fig.net/pub/fig2007/papers/ts_7b /ts07b_06_ogba_utang_1342.pdf [Accessed:September 5,2014]

Ogata, S, Sen,A (2003). Human Security Now: Commission on Human Security, Final Report, NewYork: United Nations

Okon,J (2002).Women and the Niger Delta Struggle, in Development right issues in the Niger Delta, R. Aduche Wokocha, Schaleworths Centre for Democracy and Development, pp. 66-73.

Oswald U (2008) .Gender and Disasters:Human,Gender and Environmental Security: A HUGE Challenge 'Studies of the University: Research, Counsel,Education'Publication Series of UNUEHS No.8/2008

Oswald U (2009). Facing Global Environmental Change:Environmental,Human,Energy,Food,Health and Water security Concepts.Berlin Heidelberg-New York: Springer-Verlag

Paris,R(2001).Human Security: Paradigm Shift or Hot Air? International Security no 2.26: 87-102.

Picard, M. (1995). Listening to and Learning from African Women Farmers in Valentine Udoh James (ed.), Women and Sustainable Development in Africa, Westport: Praeger.

Reardson B (1996) .Sexism and the War System. New York: Syracuse University Press

Redclift, M. (1996). Wasted: Counting the costs of global consumption. London: Earthscan.

Romaniuk,S (2009). "Engaging Gender (In) Security Gender Links". Available http:// www. Genderlinks. org.za/article/engaging-gender-in-security-2010-01-05, 2009.[Accessed August 10,2014]

Rønnfeldt, C. (1997). "Three generations of environment and security research.” Journal of Peace Research 34(4), 473-482.

Shiva V (2002). Water Wars: Privatization, Pollution And Profit. South End Press. 
Perpinan M, Vilarreal M, Oswald U(2009).Gender security in South East Asia and Trafficking of Children for ssexual Exploitation in Sexual America:HUGE Security Challenges in Facing Global Environmental Change:Environmental, Human, Energy, Food, Health and Water security Concepts.Brauch H etal (eds).Berlin Heidelberg-New York: Springer-Verlag

Suhrke, a (1995). Environmental Change, Migration and Conflict: A Lethal Feedback Dynamics?in Managing global chaos: international cooperation in issues of displacement.Chester A. Crocker et al. (eds.): Washington D.C: Carnegie Endowment for International Peace pp. 113-127

Stacey,J(1993). “Feminist Theory: Capital F, Capital T”, pp. 54-76 in Introducing Women's Studies: Feminist Theory and Practice. Victoria Robinson and Diane Richardson (eds). New York: New York University Press.

Sudarkasa,N (2005). The Status of Women in Indigenous African Societies, in Reading Gender in Africa, Andrea Cornwall (ed.), Indiana: James Currey pp.25-31.

Sandoval C (1991). "US third world feminism: The theory and method of oppositional consciousness in the postmodern world." Genders 10 (1991): 1-24.

Sen, A (1999). Development as Freedom, Oxford Press

Social Action (2009).Flames of Hell. Gas Flaring in the Niger Delta Social Development Integration Centre. Available at www.saction.org Accessed 5/1/2013

Social Action Briefing (2012). "The 2012 Floods:Human Rights and Accountability in the Management of Emergency Relief in Rivers and Bayelsa States". December, 2012.Available at www.saction.org [Accessed.5/1/2013]

Suberu, R (2006).Ethnic Minorities Conflicts and Governance in Nigeria. Ibadan, Nigeria: Spectrum Books.

Thomas, C (2000). Global governance, development and human security the challenge of poverty and inequality. London and Sterling, VA: Pluto Press.

Terriff T, Croft S, Lucy J, Morgan, P. (2005) .Security Studies Today (Malden, Polity Press)

Tickner,J(1992). Gender in International Relations: Feminist Perspectives on Achieving Global Security. New York: Columbia University Press.

Turner T, Brownhill L (2007). "Climate justice and Nigerian women"s gift to humanity," Women \& Environments International Magazine, Toronto: Spring. pp.47-48.

UNDP (2004). "Strategic Gas plan for Nigeria". Joint UNDP /World Bank Energy Management Assistance Programme (ESMA), March.

Ullman,R(1983).“Redefining Security,” International Security Vol. 8, No. 1,pp. 129-153

UNDP (2006).Niger Delta Human Development Report.Oxford.Press

UNDFPA (2003).Annual Report, Oxford University Press.

UNDP Human Development Report (1994). "Redefining Security:Human Dimensions". Oxford University Press.

United Nations High Commissioner for Refugees (UNHCR),(2002). Refugees by Numbers, 2002 Edition, Available http://www.unhcr.ch[Accessed:october,2014].

UNEP (2011) Environmental Assessment of Ogoniland, UNEP Report,Oxford Press.

UNEP "Linking Environment and Security", Available http:// www. unep. org/roe /Key Activities /Environmental Security/tabid/54360/Default.aspx[Accessed October:2014]

UNIFEM, (2007). "Lets End Violence against Women" Oxford Press.

Warren, K(ed) (1996).Ecological Feminist Philosophies Indiana University Press

Watts, M., and R. Peet. (2004). Liberating political ecology. In Liberation ecologies: Environment, Development, social movements, eds. R. Peet and M. Watts, New York: Routledge, pp.3-43.

World Development Report (2011).Conflict, Security and Development. Oxford. 